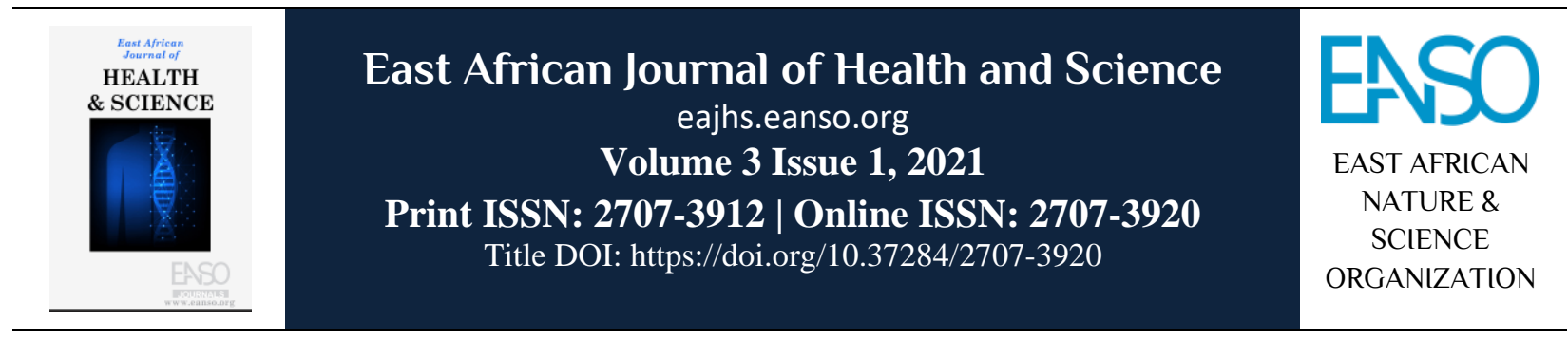

Original Article

\title{
Characteristics of Lassa Fever Outbreak in Ondo State, Nigeria, Year 2019.
} \author{
Muhammad Shakir Balogun ${ }^{3}$ \& Chioma Dan-Nwafor ${ }^{2}$ \\ ${ }^{1}$ Nigeria Field Epidemiology and Laboratory Training Program, Abuja, Nigeria \\ ${ }^{2}$ Nigeria Centre for Disease Control, Abuja, Nigeria. \\ ${ }^{3}$ African Field Epidemiology Network, Abuja. \\ ${ }^{4}$ Federal Ministry of Environment, Abuja, Nigeria \\ *Author for correspondence email: rosemaryejikeme@yahoo.com.
}

Adaora Rosemary Ejikeme ${ }^{1}$, \& Lois Olajide ${ }^{1}$, Sola Sunday Thomas ${ }^{1}$, Chimezie Anueyiagu ${ }^{2}$, Gbetsere Aghogho ${ }^{4}$, Gbenga Akinbiyi ${ }^{2}$, Amina Mohammed ${ }^{2}$, Bola Lawal $^{2}$, Famokun Gboyega ${ }^{1}$,

Article DOI: https://doi.org/10.37284/eajhs.3.1.379

\section{Date Published: ABSTRACT}

06 August 2021 Background: Lassa fever (LF) is an acute viral haemorrhagic illness of a 2-21-day incubation period that occurs in West Africa. It is endemic in Nigeria and peaks

Keywords: during the first 12 weeks of the year. On January 22, 2019, the Nigeria Centre for Disease Control (NCDC) declared an outbreak of LF following an upsurge of LF

Lassa Fever,

Outbreak,

Contact

Tracing, Ondo

State. cases in the country. A total of 213 confirmed cases including 41 deaths were reported from sixteen states including Ondo State. A multi-sectoral national rapid-responseteam (RRT) was deployed to Ondo State to characterise the outbreak, assess its determinants, and institute control measures. Methods: An Emergency Operations Center (EOC) was activated to coordinate activities. We defined a suspected case as anyone with one or more of the following symptoms: malaise, fever, headache, sore throat, cough, vomiting and either history of contact with rodents, or a probable or confirmed LF case in the past 21 days, or any person with inexplicable bleeding between January 1, 2019, to February 26, 2019, in Ondo State. A confirmed case was any suspected case with laboratory confirmation. We conducted active case search, collected data using the LF case investigation form and reviewed the existing line list. We conducted contact tracing in hospitals and affected Local Government Areas (LGA). Data was analysed using and Epi info 7.0. Results: We identified $287 \mathrm{LF}$ suspected cases in 6 LGAs; 118 were confirmed with 21 deaths (case fatality rate: $17.8 \%$ ). The mean age was $39.2 \pm 20$ years with a male-to-female ratio of 1.3:1. Of the 1,269 contacts line-listed, 20 became symptomatic, while 14 (70.0\%) were confirmed positive. The secondary attack rate was $1.1 \%$. Conclusion: The confirmed cases were more of primary cases, hence the need to focus more on reducing rodent-

115 | This work is licensed under a Creative Commons Attribution 4.0 International License. 
to-human transmission of LF. We recommend continuous education on community and health facility infection prevention control, contact tracing and enforcement of environmental sanitation measures across the state to mitigate future outbreaks.

\section{APA CITATION}

Ejikeme, A., Olajide, L., Thomas, S., Anueyiagu, C., Aghogho, G., Akinbiyi, G., Mohammed, A., Lawal, B., Gboyega, F., Balogun, M., \& Dan-Nwafor, C. (2021). Characteristics of Lassa Fever Outbreak in Ondo State, Nigeria, Year 2019. East African Journal of Health and Science, 3(1), 115-125. https://doi.org/10.37284/eajhs.3.1.379.

\section{CHICAGO CITATION}

Ejikeme, Adaora, Lois Olajide, Sola Thomas, Chimezie Anueyiagu, Gbetsere Aghogho, Gbenga Akinbiyi, Amina Mohammed, Bola Lawal, Famokun Gboyega, Muhammad Balogun, and Chioma Dan-Nwafor. 2021. "Characteristics of Lassa Fever Outbreak in Ondo State, Nigeria, Year 2019". East African Journal of Health and Science 3 (1), 115-25. https://doi.org/10.37284/eajhs.3.1.379.

\section{HARVARD CITATION}

Ejikeme, A., Olajide, L., Thomas, S., Anueyiagu, C., Aghogho, G., Akinbiyi, G., Mohammed, A., Lawal, B., Gboyega, F., Balogun, M. and Dan-Nwafor, C. (2021) "Characteristics of Lassa Fever Outbreak in Ondo State, Nigeria, Year 2019", East African Journal of Health and Science, 3(1), pp. 115-125. doi: 10.37284/eajhs.3.1.379.

\section{IEEE CITATION}

A. Makio, L. Musila, E. O. Odari, J. R. Ongus, \& R. Sang, "Characteristics of Lassa Fever Outbreak in Ondo State, Nigeria, Year 2019.”, EAJHS, vol. 3, no. 1, pp. 115-124, Aug. 2021.

\section{MLA CITATION}

Ejikeme, Adaora, Lois Olajide, Sola Thomas, Chimezie Anueyiagu, Gbetsere Aghogho, Gbenga Akinbiyi, Amina Mohammed, Bola Lawal, Famokun Gboyega, Muhammad Balogun, and Chioma Dan-Nwafor. "Characteristics of Lassa Fever Outbreak in Ondo State, Nigeria, Year 2019”. East African Journal of Health and Science, Vol. 3, no. 1, Aug. 2021, pp. 115-2, doi:10.37284/eajhs.3.1.379.

\section{INTRODUCTION}

Lassa fever is a zoonotic acute viral haemorrhagic illness with an incubation period of 2-21 days that occurs in West Africa. The virus is a single-stranded RNA virus belonging to the family Arenaviridae (Dan-Nwafor et al., 2019). The animal reservoir or host of Lassa virus (LASV) is a rodent of the genus Mastomys, commonly known as the "multimammate rat". Mastomys rats infected with LASV do not become ill, but they can shed the virus in their urine and faeces (Dan-Nwafor et al., 2019). Signs and symptoms of LF typically occur 1-3 weeks (incubation period) after the patient comes into contact with the virus. About $80 \%$ of LF symptoms are mild and are undiagnosed. Mild symptoms include slight fever, general malaise and weakness, and headache. In 20\% of infected individuals, the disease may progress to more serious symptoms including haemorrhaging (in gums, eyes, or nose, as examples), respiratory distress, repeated vomiting, facial swelling, pain in the chest, back, and abdomen, shock, hearing loss, tremors, and encephalitis. Death may occur within two weeks after symptom onset due to multi-organ failure (Shaffer et al., 2014a). The most common complication of LF is deafness which in many cases is permanent. Approximately $15 \%-20 \%$ of patients hospitalised for LF die from the illness (Dahmane et al., 2014). However, only $1 \%$ of all LASV infections results in death. The death rates for women in the third trimester of pregnancy are particularly high. Spontaneous abortion is a serious complication of infection with an estimated 95\% mortality in foetuses of infected pregnant mothers ("Lassa Fever in Pregnancy: Report of 2 Cases Seen at the University College Hospital, Ibadan," n.d.).

During epidemics, the case fatality rate can reach $50 \%$ in hospitalised patients (Ilori, Furuse, et al., 2019a). Anyone who comes into close contact with a person carrying the virus is at risk of infection. Primary transmission of LF is through contact with the contaminated excreta of $M$ natalensis rodents deposited on floors, tables, beds, and food. Secondary human-to-human transmission can also occur mainly between individuals caring for sick patients. Nosocomial transmission and outbreaks in healthcare facilities in endemic areas represent a significant burden on the healthcare system 
(Ijarotimi, Ilesanmi, Aderinwale, AbiodunAdewusi, \& Okon, 2018). Hospital laboratory transmission particularly in hospitals lacking adequate infection prevention and control (IPC) measures. Ribavirin, an antiviral drug, has been used with success in LF patients (Rosenke et al., 2018). It has been shown to be most effective when given early in the course of the illness. Patients should also receive supportive care consisting of maintenance of appropriate fluid and electrolyte balance, oxygenation and blood pressure, as well as treatment of any other complicating infections (VIRAL HAEMORRHAGIC FEVER, n.d.). Lassa fever can be prevented through regular hand washing, storage of food in containers with lids, keeping homes clean and tidy to discourage rats from entering, keeping a cat, cook all foods thoroughly("On the trail of Lassa fever in southern Nigeria," n.d.). Lassa fever has been known since the 1950s, but the virus was not identified until 1969 when two missionary nurses died from it in the town of Lassa, North-western Nigeria (Richmond \& Baglole, 2003). It is endemic in parts of West Africa including Sierra Leone, Liberia, Guinea, and Nigeria. An estimated 100,000 to 300,000 infections of LF occur annually, with approximately 5,000 deaths ("Mathematical Modelling and Analysis of Transmission Dynamics of Lassa Fever," n.d.).

\section{Nigeria Experience}

Lassa fever outbreaks have occurred in various parts of Nigeria. In a previous study, antibodies to LF were found in all locations in Nigeria (Sorungbe, Tomori, Fabiyi, McCormick \& Smith, 1988). Nigeria recorded its largest LF outbreak in 2018 with 3,498 suspected cases out of which 633 were confirmed positive and 171 deaths in confirmed cases with a case fatality rate of $27 \%$ ("Nigeria Centre for Disease Control," n.d.-a). These were reported from 93 LGAs in 22 states and the Federal Capital Territory. Forty-four health workers were affected across 7 states with 10 deaths recorded among the health workers. In early January 2019, the NCDC situation report for week 1 (January 1-6, 2019) showed that a total of 57 suspected cases had been reported. Of these, 25 were confirmed positive and 32 were negative with 7 deaths, with a case fatality rate (CFR) of $28.0 \%$ ("Nigeria Centre for Disease Control," n.d.-a). Since the identification of the virus in Nigeria in 1969, yearly outbreaks have been reported in parts of the country and more recently in some states including Ondo State, which contributed 8 new confirmed cases in the same situation report.

On January 22, 2019, the Nigeria Centre for Disease Control (NCDC) declared an outbreak of LF following an increase in the number of LF cases in the country ("Nigeria Centre for Disease Control," n.d.-b). From $1^{\text {st }}$ to January 27, 2019, a total of 213 confirmed cases including 41 deaths were reported from 16 states (Edo, Ondo, Ebonyi, Bauchi, Plateau, Taraba, Gombe, Anambra, Kaduna, Kwara, FCT, Benue, Rivers, Nasarawa and Kogi States) across 40 Local Government Areas (LGAs). This represented a significant increase in the number of cases reported compared to the same period in 2018 .

Ondo situation report of epidemiological week 4 (January 1 to 23, 2019) showed a cumulative of 100 suspected cases, 51 laboratory-confirmed cases, 2 health workers infected, 32 cases on admission, 9 deaths in confirmed cases. The distribution of the cases across LGAs showed that Owo had the highest number of cases (37), followed by Ose (9), Akoko Southwest (3) and Akure North cases (2). Two neighbouring LGAs Owo and Ose are the boundaries of the state with neighbouring Edo State which is also known to be endemic for LF. In the outbreak of 2015/2016, out of 149 deaths reported, 10 were healthcare workers. Many LGAs in Ondo State have yearly outbreaks of LF which often affect health workers who are particularly at risk in resource-poor settings like Nigeria due to lack of availability and use of IPC materials (Ijarotimi et al., 2018).

A multi-sectoral one health national rapid response team (RRT) was deployed to Ondo State to support response activities, prevent further spread, decrease morbidity and mortality, and carry out field investigations. The findings in this study should lead to further LF research and provide guidance to those preparing to respond to future outbreaks. We described the epidemiology of the LF outbreak in Ondo State. 


\section{METHODS}

\section{Study Area}

Ondo State with Akure, the capital city is located in the South-West region of Nigeria and consists of 18 LGAs. It is bordered by Delta, Edo, Ekiti, Kogi, Ogun and Osun States which is known to be endemic for LF. The population was 4,671,700 in 2016 based on the 2006 population census ("Ondo (State, Nigeria) - Population Statistics, Charts, Map and Location," n.d.). It covers an area of $15,500 \mathrm{~km}^{2}$ with longitudes $40151 \mathrm{E}$ and $60001 \mathrm{E}$, latitudes 50 $451 \mathrm{~N}$ and $70451 \mathrm{~N}$ which are to the north of the equator, and a high daily temperature of about 30 ${ }^{0} \mathrm{C}$. The majority of the citizens are civil servants, traders, and livestock farmers.

\section{Study Design}

We conducted a descriptive cross-sectional study of the LF outbreak in Ondo state between January 1 February 26, 2019.

\section{Case Definitions}

We defined a suspected case of LF as anyone with illness meeting 1 of the following criteria: 1) $>1$ signs/symptoms (e.g., malaise, fever, headache, sore throat, cough, nausea, vomiting, diarrhoea, myalgia, central chest pain or retrosternal pain, and hearing loss) and a history of contact with excreta or urine of rodents; 2) >1 signs/symptoms and a history of contact with a person with probable or confirmed LF within 21 days of symptom onset; or 3) inexplicable bleeding or haemorrhaging ("National Guidelines for Lassa Fever Case Management - Nigeria | ReliefWeb," n.d.). Probable LF cases were defined as any suspected case in a patient who died without the collection of a specimen for laboratory testing("National Guidelines for Lassa Fever Case Management Nigeria | ReliefWeb," n.d.). Confirmed LF cases were defined as any suspected case with a laboratory confirmation (positive for IgM antibody, reverse transcription PCR [RT-PCR], or virus isolation) ("National Guidelines for Lassa Fever Case Management - Nigeria| ReliefWeb," n.d.).

\section{Contact Tracing}

We defined a contact as a person having close personal contact with a patient (living with, caring for) or a person testing the laboratory specimens of a patient in the 3 weeks after the onset of the illness. We recorded and followed the person up daily for 21 days. If the contact developed symptoms, blood samples were collected and tested for LF.

\section{Active Case Search}

We conducted an active case search in hospitals and communities in affected LGAs. We reviewed the registers and case notes.

\section{Data Collection}

We collected data of all suspected LF cases reported to the Disease surveillance and notification officer (DSNO) for each Local Government Area and the State Epidemiologist. Samples were collected and tested for all suspected cases according to the NCDC LF case management guidelines. If the test was positive, detailed demographic (age, sex, and residential address), clinical (symptoms, outcome, and administration of ribavirin), and epidemiologic (occupation, onset date, and exposure history) information were collected by using a national case investigation form (CIF). All suspected, probable, and confirmed cases were line-listed, and the information in the CIFs analysed. The projected population figures of each LGA were obtained from a report based on data from the National Population Commission of Nigeria and the National Bureau of Statistics ("Ondo (State, Nigeria) - Population Statistics, Charts, Map and Location,” n.d.).

\section{Data Management}

Data was entered and analysed using Epi Info version 7.0. We calculated frequencies, proportions and estimated odds ratios (OR). We conducted binomial logistic regression analyses to determine the age- and sex-adjusted odds ratio (aOR) among survived and deceased patients with laboratoryconfirmed LF.

Ethical considerations: This investigation was performed as a part of the LF public health response in Nigeria in 2019. The investigation was not considered to research on human subjects, as per the 
US Department of Health and Human Services' Federal Policy for the Protection of Human Subjects (Otto, Holodniy, \& DeFraites, 2014). We obtained a waiver from the Federal Capital Territory (FCT) Health and Human Services Secretariat Ethical Review Committee. Permission for the study will also be obtained from Nigeria Center for Disease Control. All information obtained was kept confidential.

\section{RESULTS}

During the study period (January 1-February 26, 2019), a total of 287 suspected LF cases were reported, 4 probable cases and 118 laboratoryconfirmed cases. Table The positivity rate (i.e., the proportion of the number of laboratory-confirmed cases among all suspected cases tested) was $41.7 \%$ $(118 / 283)$ state-wide, with the highest in Ose $74.1 \%$. Among the 3 LGAs with the highest number of cases, the positive rates were $74.1 \%$ (Ose), $71.4 \%$ (Akure North) and 39.0\% (Owo) (Table 1). The CFR among the laboratory-confirmed cases in the state was $17.8 \%$ (21/118). Among the 3 mostaffected LGAs, CFR was $14.1 \%$ (Owo), $25.0 \%$ (Ose), and $0.0 \%$ (Akure North).

Table 1: Distribution of Suspected Lassa fever cases in Ondo State from January 1 - February 26, 2019

\begin{tabular}{|c|c|c|c|c|c|c|}
\hline LGA & $\begin{array}{l}\text { Population } \\
\mathbf{x 1 0 0 , 0 0 0}\end{array}$ & $\begin{array}{l}\text { Number } \\
\text { confirmed cases } \\
\text { (Death) }\end{array}$ & $\begin{array}{l}\text { Case } \\
\text { fatality } \\
\text { rate \% }\end{array}$ & $\begin{array}{l}\text { Number } \\
\text { confirmed } \\
\text { cases/100,000 } \\
\text { population }\end{array}$ & $\begin{array}{l}\text { Number } \\
\text { Probable } \\
\text { cases }\end{array}$ & $\begin{array}{l}\text { Positivity } \\
\text { rate \% }\end{array}$ \\
\hline \multicolumn{7}{|c|}{ LGAs with at least 1 confirmed case } \\
\hline $\begin{array}{l}\text { Akoko } \\
\text { South West }\end{array}$ & 308,300 & $6(4)$ & 66.7 & 1.946 & 1 & 50 \\
\hline $\begin{array}{l}\text { Akure } \\
\text { North }\end{array}$ & 176,500 & $10(0)$ & 0 & 5.666 & 0 & 71.4 \\
\hline $\begin{array}{l}\text { Akure } \\
\text { South }\end{array}$ & 486,300 & $3(0)$ & 0 & 0.617 & 0 & 20 \\
\hline Ondo West & 389,900 & $1(1)$ & 100 & 0.256 & 1 & 33.3 \\
\hline Ose & 194,600 & $20(5)$ & 25 & 10.277 & 0 & 74.1 \\
\hline Owo & 300,000 & $78(11)$ & 14.1 & 26 & 2 & 39 \\
\hline \multicolumn{7}{|c|}{ LGAs with at least 1 suspected case but no confirmed cases } \\
\hline $\begin{array}{l}\text { Akoko } \\
\text { North East }\end{array}$ & 241,700 & $0(0)$ & 0 & 0 & 0 & 0 \\
\hline $\begin{array}{l}\text { Akoko } \\
\text { North West }\end{array}$ & 286,000 & $0(0)$ & 0 & 0 & 0 & 0 \\
\hline $\begin{array}{l}\text { Akoko } \\
\text { South East }\end{array}$ & 111,300 & $0(0)$ & 0 & 0 & 0 & 0 \\
\hline Odigbo & 313,600 & $0(0)$ & 0 & 0 & 0 & 0 \\
\hline Idanre & 175,200 & $0(0)$ & 0 & 0 & 0 & 0 \\
\hline TOTAL & $2,983,400$ & $118(21)$ & $\mathbf{1 7 . 8}$ & 6.359 & 4 & 41.7 \\
\hline
\end{tabular}

Figure 1 shows the epidemic curve of the outbreak, which began in the epidemiological week 52 of 2018 (December 25, 2018, to February 28, 2019) with the index case was reported on December 2 2018. There was a steady rise in the number of cases up till week 4 of 2019 when the outbreak reached its peak. Thereafter, fluctuations in the number of cases were noted with a steady decline in the cases recorded between epidemiological weeks 7 to 9 . The median of the time lag between the onset of symptom and time seen at the facility was 5 days (interquartile range 1-17 days).

$119 \mid$ This work is licensed under a Creative Commons Attribution 4.0 International License. 
Figure 1: Epidemic curve of laboratory-confirmed Lassa fever cases in Ondo State January to February 2019

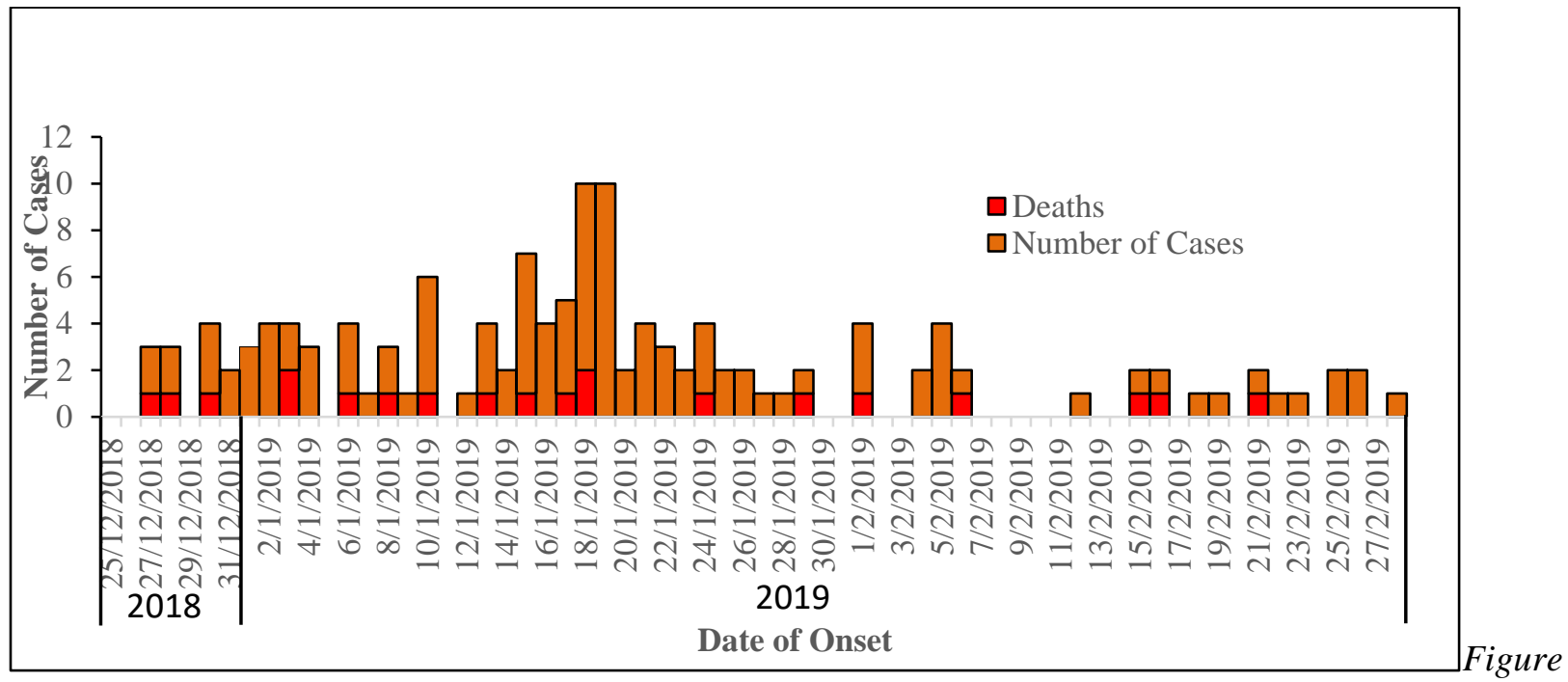

2 shows that the laboratory-confirmed cases were reported from 6 LGAs. Most (91.5\%) of the laboratoryconfirmed cases were reported from Owo, Ose and Akure North LGAs.

Figure 2: Geographic distribution of laboratory-confirmed cases by LGAs affected in Ondo State January - February 2019

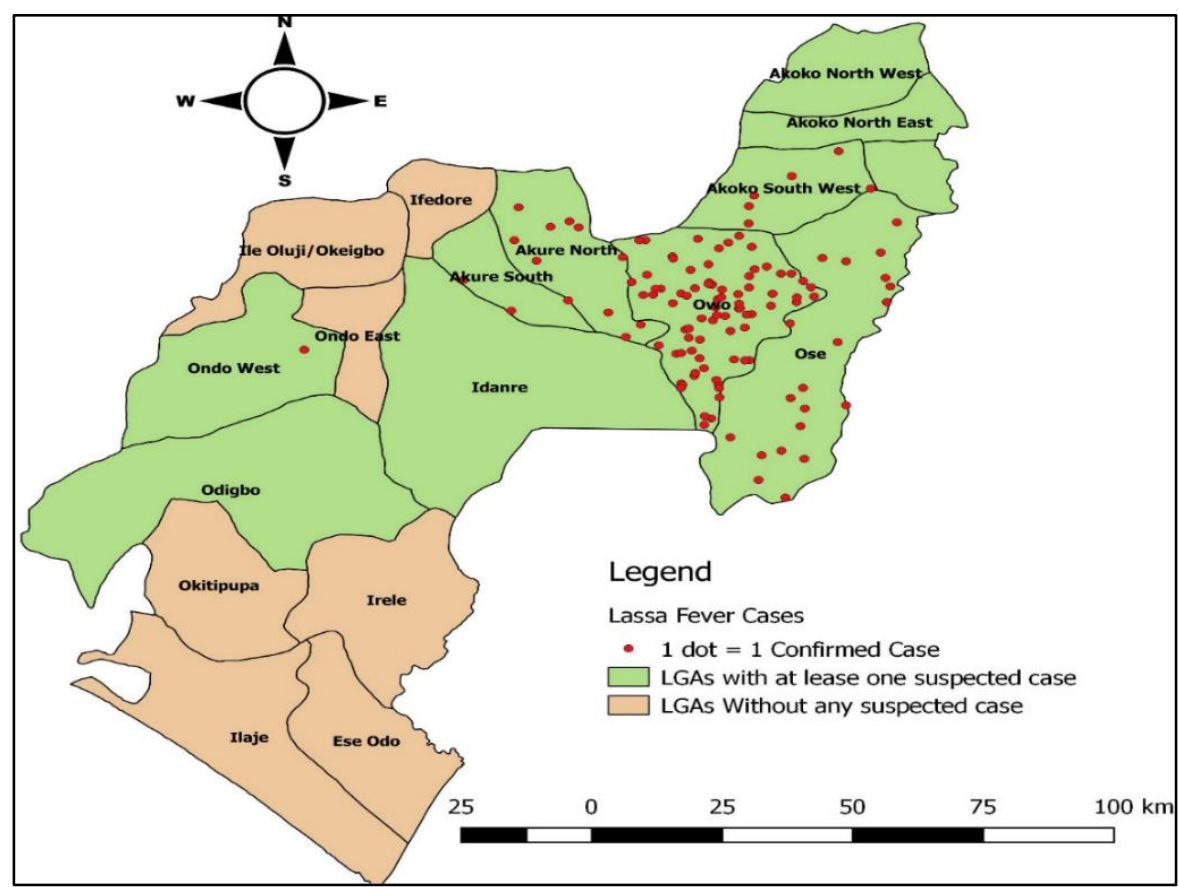

We analysed the age and sex distribution of the 118 patients with laboratory-confirmed cases (Table 2). The mean age was $39.2 \pm 20$ years; $51(43.2 \%)$ were females and 67(56.8\%) were male. CFR was lowest in the age group $20-29$ years $(0.0 \%)$ and highest in adults $50-59$ years $(28.6 \%)$. There was no statistical significance in the odds of fatal outcomes across that age group when compared to the age group 0-9 years (Table 2). CFR was higher for males (76.2\%) than female (23.8\%), but odds of fatal outcome was not statistically significant when compared to females.

$120 \mid$ This work is licensed under a Creative Commons Attribution 4.0 International License. 
East African Journal of Health and Science, Volume 3, Issue 1, 2021

Article DOI: https://doi.org/10.37284/eajhs.3.1.379

Table 2: Distribution of Age and Sex of Lassa fever cases from January 1 - February 26, 2019

\begin{tabular}{lllll}
\hline Variable & DEAD $(\mathbf{C F R})(\mathbf{N}=\mathbf{2 1}(\mathbf{1 7 . 8} \%)$ & ALIVE $(\mathbf{N}=\mathbf{9 7})$ & OR $(\mathbf{9 5 \%} \mathbf{C I})$ & P-value \\
\hline \multicolumn{2}{l}{ Age group $($ in years) } & & & \\
\hline $0-9$ & $1(4.8 \%)$ & $7(7.2 \%)$ & $(1)$ Ref & \\
$10-19$ & $1(4.8 \%)$ & $10(10.3 \%)$ & $0.70(0.03-13.17)$ & 1.00 \\
$20-29$ & $0(0.0 \%)$ & $16(16.5 \%)$ & Undefined & Undefined \\
$30-39$ & $4(19.0 \%)$ & $24(24.7 \%)$ & $1.17(0.11-12.20)$ & 1.00 \\
$40-49$ & $5(23.8 \%)$ & $12(12.4 \%)$ & $2.92(0.28-30.30)$ & 0.62 \\
$50-59$ & $6(28.6 \%)$ & $13(13.4 \%)$ & $3.23(0.32-32.48)$ & 0.63 \\
$60-69$ & $2(9.5 \%)$ & $9(9.3 \%)$ & $1.56(0.11-20.86)$ & 1.00 \\
$\geq 70$ & $2(9.5 \%)$ & $6(6.2 \%)$ & $2.33(0.17-32.59)$ & 1.00 \\
Mean age & $39.2 \pm 20$ years & & & \\
\hline Gender & & & \\
\hline M & $16(76.2 \%)$ & $51(52.6 \%)$ & $2.89(0.98-8.50)$ & 0.05 \\
F & $5(23.8 \%)$ & $46(47.4 \%)$ & $(1)$ Ref \\
\hline
\end{tabular}

During the study period, a total of 1,269 contacts of confirmed cases were identified and followed up for a 21-day follow-up period, 20 contacts developed symptoms suggestive of LF, and 14 were found to have laboratory-confirmed LF. The positive rate among symptomatic contacts was $70.0 \%(14 / 20)$, and the secondary attack rate was $1.1 \%$.

During the study period, 3 health care workers (HCWs) were infected but no deaths.

Figure 3: Contact tracing result of Lassa fever outbreak in Ondo State, January 1 - February 26, 2019

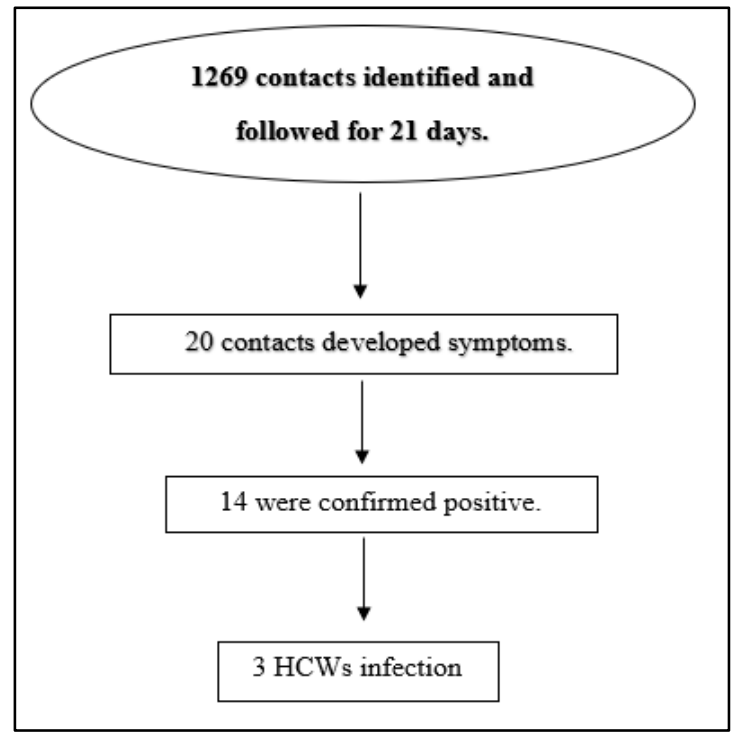

\section{DISCUSSION}

We conducted a descriptive analysis of the LF outbreak in Ondo State from January to February 2019. Out of a total of 287 suspected cases, 118 laboratory-confirmed cases were reported during the study period. Ondo State has been known to be one of the three high burden states in Nigeria endemic for LF (Ilori et al., 2019). The highest number of laboratory-confirmed cases were reported from 3 LGAs (Owo, Ose and Akure North), but out of the three LGAs, the incidence was highest in Ose. The positive rate among suspected cases was high in two (Ose and Akure North) out of the three LGAs. Our findings agree with a previous study in Ondo State, which reported confirmed cases from eight LGAs, with Akure South, Owo and Ose accounting for the highest cases (Isere et al., 2018).

Our study found that the outbreak peaked at epidemiological week 4 . The time from symptom onset to suspicion of LF was a median of 7 days (interquartile range 4-11 days); this agreed with the study by Ilori et al. (2019). This may be attributed to the days required for a health facility to report through the LGA DSNO to the state epidemiologist. This suggests a need for enhanced surveillance through case finding and prompt reporting to shorten this time gap.

The CFR among laboratory-confirmed cases during the study period was $27.1 \%$ which is significantly

121 This work is licensed under a Creative Commons Attribution 4.0 International License. 
lower than a similar study in Ondo State by E. Isere et al., who reported a high CFR of $63.2 \%$ among LF cases (Isere et al., 2018). Conversely, some other studies have also reported CFR as high as 69\% in Sierra Leone (Shaffer et al., 2014b), 40\% each by Getso et al. (2012), during an outbreak of LF in Taraba State, northern Nigeria (Getso et al., 2014; Ajayi et al. (2013), and Ajayi et al. during an outbreak of LF in Ebonyi State, south-eastern Nigeria (Ajayi et al., 2013). The low CFR in our study could be due to the improved management of LF cases in the Federal Medical Centre, Owo and early presentation of cases to the treatment facility. However, our study did not capture this. It could also be attributed to the limited duration of this study.

Although the CFR was highest among the 50-59 years age group compared to the reference group, this association was not statistically significant. This agrees with previous studies that also observed the same result (Fraser et al., 1974; Yinka-Ogunleye et al., 2018). This result however disagrees with other previous studies that reported a high CFR (Ilori et al., 2019; Abdulkarim et al., 2020). Gender was found to be associated with the odds of dying from Lassa fever. This agrees with past studies that have shown no or little difference in LF incidence between male and female patients (Bausch et al., 2001; Yalley-Ogunro, Frame, \& Hanson, 1984).

Only 14 contacts were confirmed positive for LF in this study. We did not ascertain contact with a confirmed case for other cases. Previous studies have shown that transmission of the VHFs such as LF can be related to direct contact with blood and other bodily fluids of an infected person (YalleyOgunro et al., 1984). This study however suggests more of the cases may have been borne by rodentto-human transmission. However, further study needs to be done on this. There was health care workers' infection but with no fatality. However, it is important to adhere to good infection prevention practices for protection in health facilities (Report on the Burden of Endemic Health Care-Associated Infection Worldwide Clean Care is Safer Care, 2011; Fisher-Hoch et al., 1995).

\section{Limitation}

It is important to note one major limitation of this study was limited time as we were unable to conduct a risk factor survey to identify factors associated with the cause of the outbreak.

\section{CONCLUSION}

We described the outbreak of LF in Ondo State from January to February 2019 in this study. We found that the confirmed cases were more of primary cases. There is a need to focus more on reducing rodent-human transmission of LF and carry out further environmental studies. Secondly, institute infection prevention and control measures in health facilities to prevent spread.

Although the outbreak had significantly declined before the team left, the state continued to report cases, post declaration of outbreak emergency phase over. We recommend continuous education on infection prevention control in communities, contact tracing and enforcement of environmental sanitation measures across the state to mitigate future outbreaks.

\section{ACKNOWLEDGEMENTS}

We thank all the LGA Disease surveillance officers in Ondo State who responded to this outbreak, including personnel at the healthcare facilities, Federal Medical Center, Owo, Nigeria Centre for Disease Control, World Health Organization, Alliance for International Medical Action, Médecins Sans Frontières, African Field Epidemiology Network, Federal Ministry of Agriculture and Rural Development, Federal Ministry of Environment and numerous other partners. We also express our sincerest condolences to the family and friends of those who died during the outbreak.

\section{Competing Interest}

The authors declare no competing interests.

\section{Authors' Contributions}

Adaora Rosemary Ejikeme conceptualised the study, design, implemented data acquisition, drafted the initial manuscript and data analysis. Lois 
Olajide, Sunday Sola Thomas, Chimezie Anueyiagu, Gbetsere Aghogho, Gbenga Akingbiyi, Amina Mohammed, and Famokun Gboyega implemented data acquisition and made substantial additions to the initial manuscript. Bola Lawal made a substantial revision of the initial manuscript and data analysis. Muhammad Shakir Balogun made a substantial revision of the draft manuscript. Chioma Dan-Nwafor made a substantial revision of the initial manuscript.

\section{REFERENCES}

Abdulkarim, M. A., Babale, S. M., Umeokonkwo, C. D., Bamgboye, E. A., Bashorun, A. T., Usman, A. A., \& Balogun, M. S. (2020). Epidemiology of Lassa fever and factors associated with deaths, Bauchi State, Nigeria, 2015-2018. Emerging Infectious Diseases, 26(4), 799- 801. https://doi.org/10.3201/eid260 4.190678

Ajayi, N. A., Nwigwe, C. G., Azuogu, B. N., Onyire, B. N., Nwonwu, E. U., Ogbonnaya, L. U., .. Ukwaja, K. N. (2013). Containing a Lassa fever epidemic in a resource-limited setting: Outbreak description and lessons learned from Abakaliki, Nigeria (January-March 2012). International Journal of Infectious Diseases, 17(11), e1011-e1016. https://doi.org/10.1016/j .ijid.2013.05.015

Bausch, D. G., Demby, A. H., Coulibaly, M., Kanu, J., Goba, A., Bah, A., ... Rollin, P. E. (2001). Lassa fever in Guinea: I. Epidemiology of human disease and clinical observations. Vector Borne and Zoonotic Diseases (Larchmont, N.Y.), 1(4), 269-281. https://doi.org/10.1089/153036 60160025903

Dahmane, A., Griensven, J. van, Herp, M. Van, Bergh, R. Van den, Nzomukunda, Y., Prior, J., ... Zachariah, R. (2014). Constraints in the diagnosis and treatment of Lassa Fever and the effect on mortality in hospitalised children and women with obstetric conditions in a rural district hospital in Sierra Leone. Transactions of the Royal Society of Tropical Medicine and Hygiene, 108(3), 126. https://doi.org/10.1093/T RSTMH/TRU009
Dan-Nwafor, C. C., Furuse, Y., Ilori, E. A., Ipadeola, O., Akabike, K. O., Ahumibe, A., Ihekweazu, C. (2019). Measures to control protracted large Lassa fever outbreak in Nigeria, January 1 to April 28 2019. Euro Surveillance: Bulletin Europeen Sur Les Maladies Transmissibles $=$ European Communicable Disease Bulletin, 24(20). https://doi.org/10.280 7/1560-7917.ES.2019.24.20.1900272

Fisher-Hoch, S. P., Tomori, O., Nasidi, A., PerezOronoz, G. I., Fakile, Y., Hutwagner, L., \& Mccormick, J. B. (1995). Review of cases of nosocomial Lassa fever in Nigeria: The high price of poor medical practice. BMJ, 311(7009), 857. https://doi.org/10.1136/bmj.311.7009.857

Fraser, D. W., Campbell, C. C., Monath, T. P., Goff, P. A., \& Gregg, M. B. (1974). Lassa fever in the Eastern province of Sierra Leone, 1970-1972. I. Epidemiologic studies. American Journal of Tropical Medicine and Hygiene, 23(6), 11311139. https://doi.org/10.4269/ajtmh.1974.23.11 31

Getso, K. I., Balogun, M. S., Nasidi, A., Gidado, S., Nguku, P., Oladejo, J., ... Oyemakinde, A. (2014). Lassa fever outbreak involving healthcare workers in Taraba State, Nigeria, March 2012. International Journal of Infectious Diseases, 21, 1-460. https://doi.org/10.1016/j.i jid.2014.03.871

Ijarotimi, I. T., Ilesanmi, O. S., Aderinwale, A., Abiodun-Adewusi, O., \& Okon, I. M. (2018). Knowledge of lassa fever and use of infection prevention and control facilities among health care workers during lassa fever outbreak in ondo state, Nigeria. Pan African Medical Journal, 30. https://doi.org/10.11604/pamj.2018.30.56.1312 5

Ilori, E. A., Furuse, Y., Ipadeola, O. B., DanNwafor, C. C., Abubakar, A., Womi-Eteng, O. E., ... Omilabu, S. A. (2019a). Epidemiologic and clinical features of lassa fever outbreak in Nigeria, january 1-may 6, 2018. Emerging Infectious Diseases, 25(6), 1066-1074. https://doi.org/10.3201/eid2506.181035

Isere, E. E., Fatiregun, A., Ilesanmi, O., Ijarotimi, I., Egube, B., Adejugbagbe, A., \& Famokun, G. A. 
(2018). Lessons Learnt from Epidemiological Investigation of Lassa Fever Outbreak in a Southwest State of Nigeria December 2015 to April 2016. PLoS Currents. https://doi.org/10.1371/currents.outbreaks.bc43 96a6650d0ed1985d731583bf5ded

Lassa Fever in Pregnancy: Report of 2 Cases Seen at the University College Hospital, Ibadan. (n.d.). Retrieved June 23, 2020, from https://www.hindawi.com/journals/criog/2016/9 673683/

Mathematical Modelling and Analysis of Transmission Dynamics of Lassa Fever. (n.d.). Retrieved June 23, 2020, from https://www.hindawi.com/journals/jam/2020/61 31708/

National Guidelines for Lassa Fever Case Management - Nigeria $\mid$ ReliefWeb. (n.d.). Retrieved June 23, 2020, from https://reliefweb.int/report/nigeria/nationalguidelines-lassa-fever-case-management

Nigeria Centre for Disease Control. (n.d.-a). Retrieved June 23, 2020, from https://ncdc.gov.ng/diseases/sitreps/?cat=5\&na me $=$ An update of Lassa fever outbreak in Nigeria

Nigeria Centre for Disease Control. (n.d.-b). Retrieved June 23, 2020, from https://ncdc.gov.ng/news/163/pressrelease\%3A-ncdc-initiates-response-to-risinglassa-fever-cases-in-nigeria

On the trail of Lassa fever in southern Nigeria. (n.d.). Retrieved June 23, 2020, from https://www.who.int/news-room/featurestories/detail/on-the-trail-of-lassa-fever-insouthern-nigeria

Ondo (State, Nigeria) - Population Statistics, Charts, Map and Location. (n.d.). Retrieved June 23, 2020, from https://www.citypopulation.de/php/nigeriaadmin.php?adm1id=NGA029

Otto, J. L., Holodniy, M., \& DeFraites, R. F. (2014). Public health practice is not research. American
Journal of Public Health, 104(4), 596-602. https://doi.org/10.2105/AJPH.2013.301663

Report on the Burden of Endemic Health CareAssociated Infection Worldwide Clean Care is Safer Care. (2011). Retrieved from www.who.int

Richmond, J. K., \& Baglole, D. J. (2003, November 29). Lassa fever: Epidemiology, clinical features, and social consequences. British Medical Journal, Vol. 327, pp. 1271-1275. https://doi.org/10.1136/bmj.327.7426.1271

Rosenke, K., Feldmann, H., Westover, J. B., Hanley, P. W., Martellaro, C., Feldmann, F., ... Safronetz, D. (2018). Use of favipiravir to treat lassa virus infection in Macaques. Emerging Infectious Diseases, 24(9), 1696-1699. https://doi.org/10.3201/eid2409.180233

Shaffer, J. G., Grant, D. S., Schieffelin, J. S., Boisen, M. L., Goba, A., Hartnett, J. N., ... Garry, R. F. (2014a). Lassa Fever in PostConflict Sierra Leone. PLoS Neglected Tropical Diseases, $\quad 8(3), \quad$ e2748. https://doi.org/10.1371/journal.pntd.0002748

Shaffer, J. G., Grant, D. S., Schieffelin, J. S., Boisen, M. L., Goba, A., Hartnett, J. N., ... Garry, R. F. (2014b). Lassa Fever in PostConflict Sierra Leone. PLoS Neglected Tropical Diseases, $\quad$ 8(3), e2748. https://doi.org/10.1371/journal.pntd.0002748

Sorungbe, A., Tomori, O., Fabiyi, A., McCormick, J. B., \& Smith, A. (1988). Viral Hemorrhagic Fever Antibodies in Nigerian Populations. The American Journal of Tropical Medicine and Hygiene, 38(2), 407-410. https://doi.org/10.4269/ajtmh.1988.38.407

VIRAL HAEMORRHAGIC FEVER. (n.d.).

Yalley-Ogunro, J. E., Frame, J. D., \& Hanson, A. P. (1984). Endemic Lassa fever in Liberia. VI. Village serological surveys for evidence of Lassa virus activity in Lofa County, Liberia. Transactions of the Royal Society of Tropical Medicine and Hygiene, 78(6), 764-770. https://doi.org/10.1016/0035-9203(84)90013-0 
Yinka-Ogunleye, A., Ipadeola, O., Saleh, M., Ilori, E., Dan-Nwafor, C., Nwachukwu, W., ... Ihekweazu, C. (2018). 2016/2017 Lassa fever outbreak in Nigeria: age and sex have no effect on treatment outcome. Pan African Medical Journal Conference Proceedings, 2. https://doi.org/10.11604/pamj.cp.2018.8.3.705

125 | This work is licensed under a Creative Commons Attribution 4.0 International License. 